\title{
単体ガス成分に対する家庭用空気清浄機の性能試験方法に関する検討 THE PERFORMANCE TESTING METHOD FOR DOMESTIC AIR CLEANERS TO REMOVE SINGLE GASEOUS CHEMICAL SUBSTANCE
}

\author{
長谷川 麻子*, 羽田崇秀**, 小峯裕已***, 鎌田元 康**** \\ Asako HASEGAWA, Takahide HATA, Hiromi KOMINE \\ and Motoyasu KAMATA
}

\begin{abstract}
This paper aims to establish the performance testing method for domestic air cleaners to remove single gaseous chemical substance. At first, 4 experiments were performed with gaseous formaldehyde(HCHO) on 5 air cleaners : (1) filtration test by concentration-decay, (2) re-circulating test by concentration-decay, (3) filtration test by constant-emission, and (4) re-circulating test by constant-emission. These results suggest that type-(3) as same as a penetration test for gas-removal filters is appropriate and removal efficiency $(\eta)$ as same as arrestance of filters obtained from this test is the best index to evaluate the performance. Further experiments with gaseous toluene and xylene were conducted. This testing method and index can apply to all air cleaners in spite of its mechanism.
\end{abstract}

Keywords : domestic air cleaners, chemical substances, performance testing, removal efficiency, equivalent air change rate 家庭用空気清浄機、化学物質、性能試験、除去率、相当換気量

\section{1. 背景および目的}

住宅内における化学物質污染の対策としては、発生量が少ない建 材を使用することや、積極的に外気を取り入れる換気が有効である が、分譲や賃貸の住宅に入居せざるを得ない場合は建築的対策を施 す段階からかかわることができず、居住者が実施可能な対策として は、化学物質を除去できる家庭用空気清浄機(以下、空気清浄機と略 記)の利用があげられる。しかしながら、その選択に必要な除去性能 については、その試験方法やメーカーによる表示方法が統一されて おらず、比較が困難である。また、室内空気污染の要因となる化学 物質のうちホルムアルデヒド(HCHO)は、発がん性が明らかで、徐放 性を有するため、他の揮発性有機化合物(VOCs)成分に比べて長期に わたり放散されることから、除去対象として優先する必要がある。

空気清浄機について、ガス状物質の除去性能を取り扱う標準的な 試験方法は、(社)日本電機工業会(以下、JEM と略記)および(財)日本 規格協会(以下、JIS と略記)が定める 2 つの方法がある。前者は、「脱 臭性能試験」として規定された方法で、測定ボックスとよばれる $1 \mathrm{~m}^{3}$ の密閉チャンバー内にタバコを用いて化学物質を発生させ、タバコ の燃焼が終わった後にアンモニア、アセトアルデヒド、酢酸の初期 濃度を測定し、その後空気清浄機を 30 分運転してから残存ガス濃度

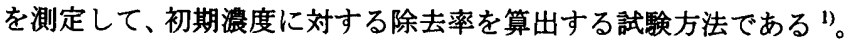
後者は、密閉チャンバー内に一定濃度の $\mathrm{NO}_{2}$ および $\mathrm{SO}_{2}$ ガスを供給
しながら空気清浄機を運転し、10 分後の吸込口および吹出口におけ る濃度から除去率を算出する試験方法である ${ }^{2)}$ 。従来、空気清浄機 に要求される性能は主に除じんや消臭であったため、これら現用の 性能試験方法には、対象物質として HCHO が含まれておらず、室内 空気污染の要因物質を対象とした実用的で沉用性のある試験方法を 確立するべきである。

一方、JISには、HCHO ガスなどを対象に、一定の污染物質を供給 するダクト内にフィルターを設置し、その上流側および下流側の濃 度から除去率を算出する「ガス除去フィルター性能試験方法 $]^{3) か ゙ あ ~}$ る。これは一般に「ワンパス試験」と呼ばれ、フィルターの化学物質 除去性能をあらわすのに適している。

実際の居室は、室内の建材や家具などから常時 HCHO が発生し、 自然換気あるいは機械換気によりある程度の換気量が確保された環 境である。このような室内で空気清浄機を運転する場合に得られる 除去性能を知るためには、チャンバー内の換気量を一定にし、ガス 状物質を常時供給しながら、その污染空気と空気清浄機によって処 理された清浄空気とが混合する環境下での性能試験を行う必要があ る。このような試験方法による空気清浄機の HCHO 除去効果につい

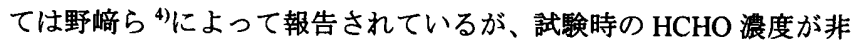
常に高く、実空間において測定されうる濃度範囲で性能試験を行う ことが望まれる。

\footnotetext{
* 能本大学工学部環境システム工学科 助手・博士 (工学)

** マツミハウジング侏）工修

***千葉工業大学工学部建築都市環境学科 教授・工博

**** 東京大学大学院工学系研究科建築学尃攻 教授 $\cdot$ 工博
}

Research Assoc., Dept. of Architecture and Civil Eng., Faculty of Eng., Kumamoto University, Dr. Eng.

Matsumi Housing, M. Eng.

Prof., Dept. of Architecture, Faculty of Eng., Chiba Institute of Technology, Dr. Eng.

Prof., Dept. of Architecture, Grad. Sch. of Eng., The University of Tokyo, Dr. Eng. 
以上の試験方法を参考にして、空気清浄機の性能試験方法を分類 すると、污染物質ガスの発生方法として「濃度減衰法」および「定常発 生法」の 2 条件が考えられ、試験方法として空気清浄機の吸込口およ び吹出口の濃度から除去率を算出する「ワンパス試験」と、空気清浄 機運転中のチャンバー内濃度の時間変化を測定する「再循環試験」の 2 種類が考えられる。本研究では、ステンレス製大型チャンバーを 用いて、HCHO 除去をうたう市販の空気清浄機を対象に、HCHO 濃 度を実際の新筑住宅における実測結果に基づいた範囲とし、「濃度减 衰法」および「定常発生法」の 2 つの条件下で、「ワンパス試験」と「再 循環試験」の計 4 種類の実験を行う。これらの結果から、除去原理の 異なる空気清浄機について、同じ指標で HCHO 除去性能をあらわす ことができる試験方法を検証する。さらに、室内空気対策研究会の 実態調查により戸建住宅において多量に検出され、かつ厚生労働省 による規制対象に含まれるトルエン、キシレンについても同様の試 験を行うことにより、HCHO 以外の単体ガス成分に対する除去性能 を確認する。これらの実験結果から、除去原理にかかわらず空気清 浄機の化学物質除去性能をあらわすことができる、家庭用空気清浄 機の試験方法を確立することを目的とする。

\section{2. 検討内容}

空気清浄機の性能試験において、污染物質ガスの発生方法として は、JEM で採用されているような濃度堿衰法が容易であるが、空気 清浄機の除去率と処理風量の積によって得られる清浄空気量(以下、 「相当換気量」と称する)とチャンバーの気積との関係によっては、ご く短時間に濃度が著しく減衰し、除去率が高い機種ほど正確な測定 が困難になることが予想される。そこで、簡易な HCHO ガス発生器 具(6.1 に詳しく述べる)を考案し、これを用いて定常発生法による性 能試験を容易に行えるようにした。

本研究において行う実験は、以下の 4 種類である。

(a) 濃度堿衰法・ワンパス試験(図 1)：濃度減衰法は、チャンバーを 密閉状態とし、換気量が 0 の条件下で行う。空気清浄機の吸込・吹 出口にはアルミ製のダクト(長さ $0.5 \mathrm{~m})$ を取付け、吸込口の前面パネ ルおよび吹出ログリルの中央にテフロンチューブを固定してサンプ リングロを設ける。チャンバー内を所定の $\mathrm{HCHO}$ 濃度にした後、空 気清浄機を運転し、5 10 分後の吸込口および吹出口擞度を測定し て、これらの結果から下式により除去率 $\eta_{d}[\%$ \% 算出する。

$$
\eta_{d}=\left(1-C_{\text {out }} / C_{\text {in }}\right) \times 100
$$

\section{ここに、 $C_{i n}:$ 空気流入側のガス濃度 $[\mathrm{ppm}]$}

$$
C_{\text {out }}: \text { 空気流出側のガス濃度 }[\mathrm{ppm}]
$$

(b) 濃度減衰法・再循環試験(図 2)：換気量が 0 の密閉チャンバー内 を所定の HCHO 濃度にし、空気清浄機の運転開始 30 分後、1 時間 後、その後 1 時間ごとに残存濃度を測定する。

(c) 定常発生法・ワンパス試験(図 3)：チャンバー内の給・排気口と 空気清浄機の吸込・吹出口とを接続し、空調機および排気ファンの 風量と空気清浄機の処理風量を等しくして、空調機、空気清浄機、 排気ファンを直列接続とする。空調機によって温・湿度が調節され た供給空気に一定の HCHO ガスを常時混入し、空気清浄機の吸込口 およ゙び吹出口の $\mathrm{HCHO}$ 濃度を同時に測定して、下式により除去率 $\eta_{O P}[\%]$ 算出する。

$$
\eta_{O P}=\left(1-C_{\text {out }} / C_{\text {in }}\right) \times 100
$$

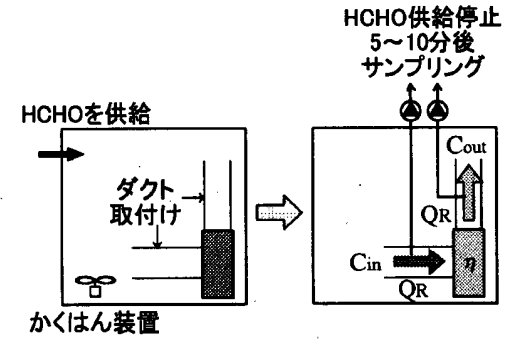

図 1 濃度減衰法・ワンパス試験の概要

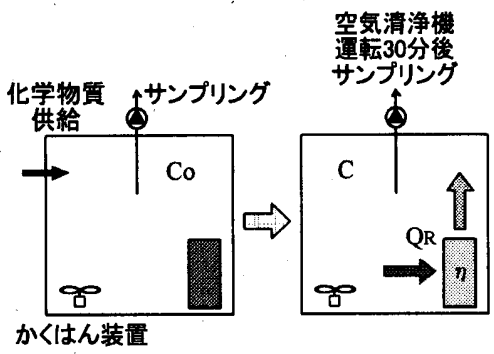

図 2 濃度減衰法・再循環試験の概要

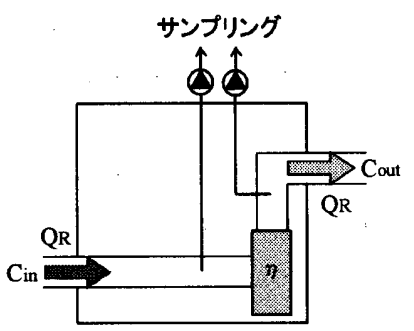

图 3 定常発生法・ワンパス試験の概要

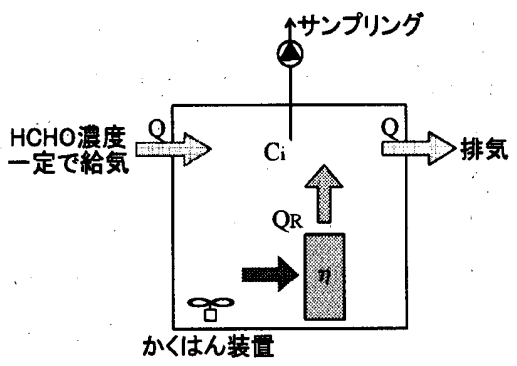

図 4 定常発生法・再循環試験の概要

(d) 定常発生法・再循環試験(図 4)：本実験は、住宅における一般的 な換気回数 0.5 回 $/ \mathrm{h}$ に相当する一定の換気量(約 $7 \mathrm{~m}^{3} / \mathrm{h}$ )の条件下で行 う。チャンバー内に任意の HCHO を定常発生させて、空気清浄機の 運転開始 30 分後にチャンバー内 $\mathrm{HCHO}$ 濃度を測定する。さらに、 チャンバー内 $\mathrm{HCHO}$ 濃度が平衡に達するまで、空気清浄機の運転開 始後 1 時間ごとに測定する。

物質平衡の式により、 $\eta_{d}$ あるいは $\eta_{O P}$ を用いてチャンバー内濃度 の時間変化を予測した減衰曲線は、それぞれ赛験(b)あるいは(d)の測 定結果と一致するはずである。

濃度減衰法の場合は、チャンバー内空気が $\eta_{d}[-]$ と空気清浄機の処 理風量 $Q_{R}\left[\mathrm{~m}^{3} / \mathrm{h}\right]$ を乗じた清浄空気によって浄化されることになるの で、初期浱度が $C_{s}\left[\mathrm{mg} / \mathrm{m}^{3}\right]$ のき、ある時間におけるチャンバー内濃 度 $C\left[\mathrm{mg} / \mathrm{m}^{3}\right]$ は、 


$$
C=C_{s} e^{-\frac{\eta_{d} Q_{R_{t}}}{V}}
$$

とあらわすことができる。

定常発生法の場合は、まず $d t$ 時間中の $\mathrm{HCHO}$ に関する物質平衡を 考えると、下式になる。

$$
\left(C o \cdot Q_{F}+M\right) d t-C i\left(Q_{F}+\eta_{O P} \cdot Q_{R}\right) d t=V \cdot d C i
$$

ここに、M: $\mathrm{HCHO}$ 発生量 $[\mathrm{mg} / \mathrm{h}]$

$$
\begin{aligned}
& C o: \text { 供給空気中のバックグラウンド濃度 }\left[\mathrm{mg} / \mathrm{m}^{3}\right] \\
& C i: \text { チャンバー内 } \mathrm{HCHO} \text { 濃度 }\left[\mathrm{mg} / \mathrm{m}^{3}\right] \\
& Q_{F}: \text { チャンバー内換気量 }\left[\mathrm{m}^{3} / \mathrm{h}\right] \\
& \eta_{O P}: \text { ワンパス除去率[-] }
\end{aligned}
$$

供給空気はケミカルフィルターを介しており、その HCHO 濃度は無 視できるほど小さいので $C o=0$ とすると、(4)式は、

$$
\left\{M-C i\left(Q_{F}+\eta O_{O P} \cdot Q_{R}\right)\right\} d t=V \cdot d C i
$$

となり、この微分方程式を解くと、

$$
\ln a\left(\frac{M}{Q+\eta_{O P} \cdot Q_{R}}-C i\right)=-\frac{Q+\eta_{O P} \cdot Q_{R}}{V} t
$$

ここで、初期条件として時間 $t=0$ のとき、 $C i=C s$ (空気清浄機運転前 の定常濃度 $\left.\left[\mathrm{mg} / \mathrm{m}^{3}\right]\right)$ なので、積分定数 $\mathrm{a}$ は

$$
a=\frac{1}{\frac{M}{Q+\eta_{O P} \cdot Q_{R}}-C s}
$$

となり、下式が決まる。

$$
C i=\frac{M}{Q_{F}+\eta_{O P} \cdot Q_{R}}\left(1-e^{-\frac{Q_{F}+\eta_{O P} Q_{R}}{V}}\right)+C s \cdot e^{-\frac{Q_{F}+\eta_{O P} Q_{R}}{V} t}
$$

また、空気清浄機の除去性能が実験中に劣化することなく一定で あれば、ガス発生方法に関わらず $\eta_{d}=\eta_{O P}$ となるはずである。

以上のことがらについて、4 種類の実験結果から整合性を検討し、 空気清浄機の化学物質除去性能に関する試験方法を提案する。実験 を行うにあたり、はじめに試験装置の基本性能について検討した。

\section{3. 試験装置の基本性能}

\section{1 試験装置概要}

図 5 に、本試験装置の概要を示す。

本試験装置は、ステンレス製大型チャンバー(以下、チャンバー) および $\mathrm{HCHO}$ 発生装置から構成されている。チャンバーは $2,280 \times$ $2,400 \times 2,550^{\mathrm{H}}$ 、気積約 $14 \mathrm{~m}^{3} 、$ 空調機から温・湿度を制御した空気が ケミカルフィルターを通過して浄化され、チャンバー内に供給され る。チャンバー外部の恒温実験室内には、発生源となるホルマリン 溶液あるいはパラホルムアルデヒドを投入するためのステンレス製 密閉容器を恒温水槽内に浸漬し、密閉容器内部の HCHO ガスをコン プレッサーによって圧送できる HCHO 発生装置を製作、設置した。 ここから圧送された HCHO ガスはチャンバー内に放散され、チャン バー内の濃度が均一になるように扇風機でかくはんしている。

本試験装置の基本性能を確認するため、以下の実験を行った。

(1) チャンバー内温・湿度の安定性 : 濃度減衰法による試験は、空 調機を停止して密閉状態で行った。空調機停止後のチャンバー内温 度および相対湿度は、簡易記録計を用いて 24 時間測定した。

(2) チャンバー内換気量の制御性: 換気量 0 (密閉状態)については、 チャンバー内に HCHO ガスを所定の濃度で与えて、時間変化を測定

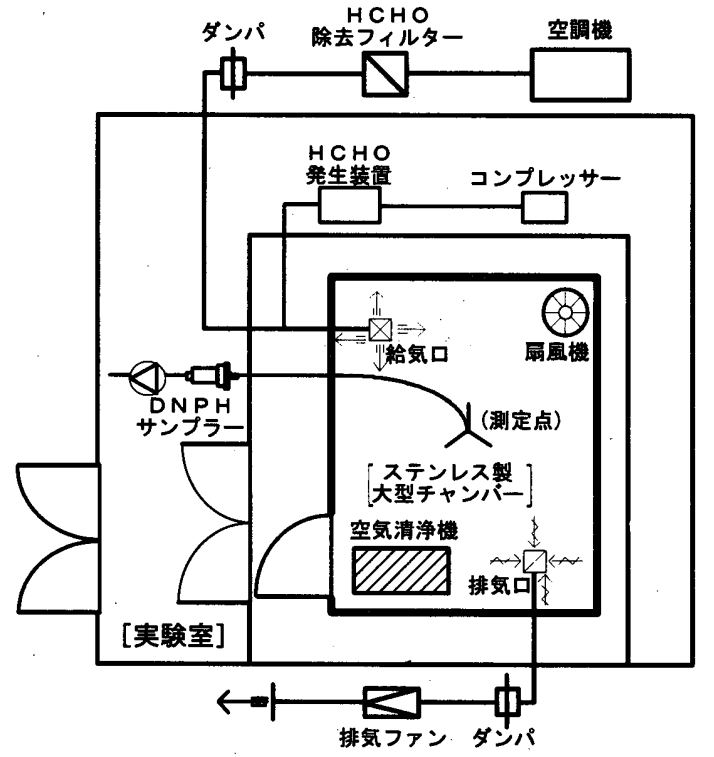

図 5 試験装置概要(平面)

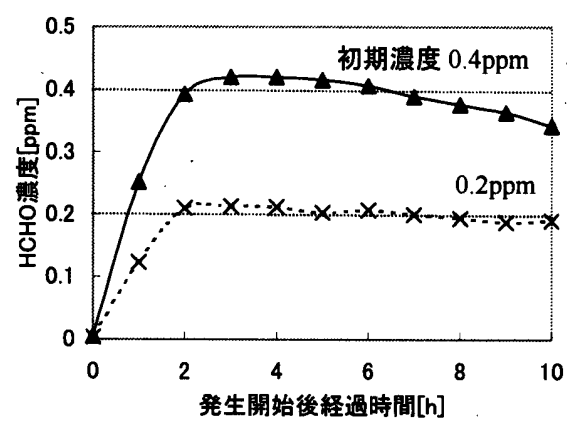

図 6 チャンパー内 $\mathrm{HCHO}$ 濃度の時間变化 $<$ 密閉状態 $>$

した。また、本試験装置は、ダンパの開閉と、空調機の給気ファン および排気ファンを周波数制御することにより、チャンバー内換気 量を変化させることができる。 $\mathrm{CO}_{2}$ ガス減衰法により、任意の換気 量の測定を行った。

(3) チャンバー内バックグラウンド濃度 : チャンバー内が空の状態 で、HCHO および VOCs の濃度を測定した。

(4) $\mathrm{HCHO}$ 発生装置の制御性および安定性 : 本発生装置は、HCHO 発生源としてホルマリン溶液あるいはパラホルムアルデヒドを用い、 それらの投入量、恒温水槽の温度、圧送空気量によって、換気のあ るチャンバー内を任意の濃度で一定に維持できる。DNPH-HPLC 法 により測定した。

\section{2 チャンバー内温·湿度の安定性}

チャンバー内温度および相対湿度は、空調機運転停止後 24 時間に わたって測定した結果ほとんど変動がなく、濃度堿衰法による除去 性能試験に必要な時間は一定に維持できることがわかった。

\section{3 チャンバー内換気量の制御性}

図 6 に、DNPH-HPLC 法によって測定した、密閉状態におけるチ ヤンバー内 $\mathrm{HCHO}$ 濃度の時間変化を示す。

0.2、0.4ppm を目標濃度として $\mathrm{HCHO}$ 発生装置を運転した場合に ついて、それぞれ 3 回試験を行ったところ、ほぼ同様の濃度変化が 
得られ再現性が確認された。チャンバー内 $\mathrm{HCHO}$ 濃度の測定結果か ら、換気量のない密閉状態でも若干減衰していることがわかる。こ れは、チャンバー内はステンレス製で吸・脱着がほとんどないことか ら、給·排気ダクトからの漏気によるものと考えられる。しかしなが ら、この自然减衰から算出した換気量は $0.6 \sim 1 \mathrm{~m}^{3} / \mathrm{h}$ であり、空気清 浄機の風量に対して非常に小さいので、実験時間中における影響は 無視できると判断した。

また、空調機の給気ファンおよび排気ファンの周波数と風量との 相関関係が得られ、周波数制御により任意の換気量に維持できるこ とを確認した。

\section{4 チャンパー内バックグラウンド濃度}

空のチャンバー内の HCHO および VOCs 濃度を測定した結果、い ずれも検出下限值以下であり、空調機運転中は外気濃度と同等程度 (0.004ppm)であったので、以降の実験には影響がないと判断した。

\subsection{HCHO 発生装置の制御性および安定性}

図 7 に、DNPH-HPLC 法によって測定した、換気量約 $7 \mathrm{~m}^{3} / \mathrm{h}(\doteqdot$ 換 気回数 0.5 回/h)のチャンバー内 $\mathrm{HCHO}$ 濃度の時間変化を示す。 HCHO は、圧送する空気量を一定にし、パラホルムアルデヒドを投

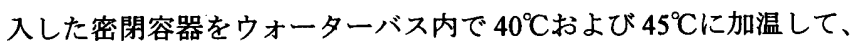
2 段階の濃度で発生させた。

HCHO 発生装置の運転開始時間を 0 として、濃度が安定するまで は 1 時間ごと、その後 $21 、 24$ 時間後に、DNPH-HPLC 法によりチャ ンバー内 $\mathrm{HCHO}$ 濃度を測定した結果、換気のある環境下であっても、 除去性能試験に必要な時間における HCHO 濃度がほぼ一定である ことがわかった。

\section{4. 空気清浄機の風量測定}

表 1 に赛験対象とした空気清浄機の仕様を、表 2 に処理風量の実 測值およびカタログ值を示す。

HCHO 除去をうたった市販の空気清浄機の中から、物理吸着式(C)、 化学分解式(B、D)、複合式(A、E)の、除去原理が異なる機種を 5 台 選択した。

「JIS C 9603 換気扇! 「)に則り、空気槽内外静圧差が 0 となるときの 吸込みノズル風量を測定して、空気清浄機の基本性能として機器処 理風量を確認し、メーカーの公称値と比較した結果、実測値のほう が小さかった。メーカーは空気清浄機に内蔵しているファンの能力 から処理風量を提示していると推察されるが、空気清浄機の吸込口 および吹出口はスリット状のパネルやグリルになっており、ほとん どの機種は吸込口にフィルターが内藏されるので、これらが処理空 気の抵抗になって実際の風量が減少していると考えられる。

運転モードの切替え以外の手段で風量を変化させると、空気清浄 機の本来の使用状態と異なり、実用的な性能評価ができなくなる恐 れがあるため、以降の実験では、カタログ值の風量によって運転モ ードを決定し、空気清浄機の吹出口や吸込口にダクトなどの抵抗が ない場合は、実測値の処理風量で稼動したものとみなすこととする。

\section{5。濃度墄衰法による性能試験}

\section{1 実験内容}

「3. 試験装置の基本性能」において基本性能を把握した約 $14 \mathrm{~m}^{3}$ の本チャンバーを用い、「4，空気清浄機の風量測定」において処理

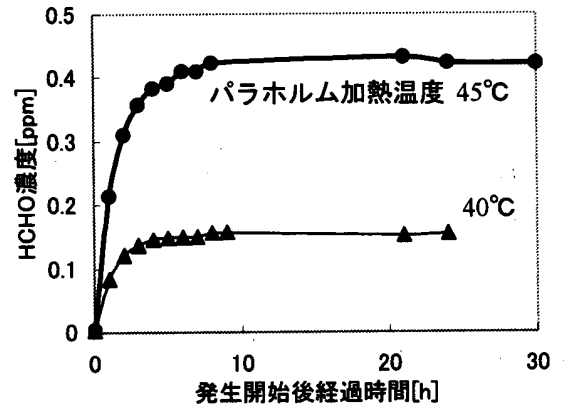

图 7 チャンパー内 $\mathrm{HCHO}$ 濃度の時間変化 <換気状態 $>$

表 1 実験対象とした空気清浄機の仕梾(カタログによる)

\begin{tabular}{|c|c|c|}
\hline & HCHO 除去原理 & 処理風量 $\left[\mathrm{m}^{3} / \mathrm{h}\right]$ \\
\hline A & 添着活性炭フィルターろ過 & $120($ 強運転 $)$ \\
\hline B & 光触媒分解除去 & 120 (標準運転) \\
\hline C & 脱臭フィルターろ過 & 120 (弱運転 $)$ \\
\hline D & プラズマ放電分解除去 & 78 (弱運転 $)$ \\
\hline E & 改質活性炭ろ過 & 114 (弱運転 $)$ \\
\hline
\end{tabular}

表 2 空気清浄機の処理風量 $Q_{R}\left[\mathrm{~m}^{3} / \mathrm{h}\right]$

\begin{tabular}{|c|c|c|c|c|c|}
\hline & 微風 & 哥 & 標準 & 強 & 急速 \\
\hline \hline$A$ & - & $52.2(60)$ & $77.0(90)$ & $115.6(120)$ & - \\
\hline B & $26.2(36)$ & $77.5(84)$ & $112.2(120)$ & $163.6(180)$ & - \\
\hline C & - & $118.1(120)$ & $164.3(180)$ & $222.0(240)$ & - \\
\hline D & $32.3(36)$ & $68.9(78)$ & $162.8(174)$ & - & $236.8(258)$ \\
\hline E & - & $1998(114)$ & $106.2(150)$ & - & $129.8(192)$ \\
\hline
\end{tabular}

※網掛けは実験時の処理風量。()内はカタログ值。

風量を確認した空気清浄機について濃度减衰法によるワンパス試験 および再循環試験を実施し、結果の整合性を検証する。

まず、ワンパス試験を行い、先述の(1)式に示す除去率 $\eta_{\mathrm{d}}$ を算出 し、(3)式に代入してチャンバー内濃度の減衰曲線を求める。次に、 再循環試験を行い、得られた実験值と、(3)式から求めた减衰曲線を 比較・検討する。

\section{2 実験条件}

$2 つ の$ 実験のいずれも、以下の条件下で実施した。

(1) チャンバー内の温・湿度は、 $25^{\circ} \mathrm{C} 、 40 \% \mathrm{RH}$ とする。

(2) チャンバー内 $\mathrm{HCHO}$ 濃度は、今までの実測結果 ${ }^{6)}$ を参考に、実 際の住宅において測定される濃度として $0.4 \mathrm{ppm}$ 以下とする。

(3) 同じ処理風量における除去性能を得るため、カタログ值で $120 \mathrm{~m}^{3} / \mathrm{h}$ に最も近い運転モードで実験を行う(表 2 網挂けの風量)。

(4) HCHO 濃度の測定方法は、標準法である DNPH-HPLC 法とし、 サンプリングに際しては、濃度レベルに応じて $10 \mathrm{~L}$ 前後を $5 \sim 10$ 分 間で捕集する。

\section{3 結果および考察}

図 8 に、濃度減衰法・ワンパス試験の実験結果を示す。チャンバ 一内の初期濃度は、0.1、0.2、0.4ppm を目標として HCHO を供給し たが、機種 A、C、E は、運転を停止していても吸込口濃度がチャン バー内初期濃度より低くなる傾向があった。これらの空気清浄機は、 $\mathrm{HCHO}$ を吸着・分解するフィルタが内蔵された機種であり、停止し 
ていても空気中の HCHO がフィルタに接触して分解されたと考え られる。しかしながら、それぞれの機種の $\eta_{d}$ は、吸込口濃度によら ずほぼ一定であり、機種ごとの差異が明らかになった。

図 9 に、濃度堿衰法・再循謤試験の実験結果を示す。チャンバー 内 $\mathrm{HCHO}$ 濃度は、空気清浄機運転開始直後から 1 時間以内で急激に 低下していることがわかる。機種 A の実験では、空気清浄機運転開 始直後の濃度低下が著しく、DNPH サンプラーの捕集に要する時間 を考慮して 30 分後の測定を行わず、運転開始後 1 時間ごとの測定し かできなかった。なお、機種 $\mathrm{E}$ は、先のワンパス試験において機種 $\mathrm{A}$ 以上の除去率が得られており、チャンバー内濃度がより短時間で 極端に低下すると予想され、HCHO 濃度測定を正確に実施すること が困難であると判断し、再循環試験を行っていない。濃度減衰法・ 再循環試験では、 $14 \mathrm{~m}^{3}$ の気積をもつ本チャンバーを用いても、空気 清浄機の運転によって HCHO 濃度が急激に低下した。ある程度の除 去率を有する空気清浄機について、あるいは本実験よりも機器処理 風量が大きい場合について除去性能を明らかにするためには、空気 清浄機の運転による濃度低堿が緩やかになるように、より大きい気 積のチャンバーが必要になると予測される。

図10に、ワンパス試験において得られた $\eta_{d}$ を用いて、(3)式によ

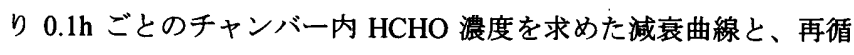
環試験において得られた濃度変化について、一例として機種 A の結 果を示す。(3)式から得られた减衰曲線は、再循環試験におけるチャ ンバー内濃度の時間変化と一致せず、空気清浄機の運転開始直後に おいて実験值よりも急激に減衰する結果となった。これは、 $\eta_{d}$ が真 の除去率よりも大きい值であったためであると推察される。他の機 種でも同様の傾向が認められた。濃度減衰法・ワンパス試験では、 空気清浄機の運転によるチャンバー内濃度の低下が著しく、また空 気清浄機の機種それぞれに吸込・吹出口の形状および大きさが異な り、機種によっては接続したダクト内の濃度分布がごく短時間で変 化していると考えられ、DNPH-HPLC 法による濃度測定から正確な 除去率を得ることが困難である可能性が高い。

\section{6. 定常発生法による性能試験}

\section{1 実験内容}

濃度減衰法による性能試験と同じチャンバーを用いて、HCHO ガ スを定常発生させたワンパス試験および再循環試験を行い、ワンパ ス除去率 $\eta O P$ から予測した濃度减衰曲線と再循環試験の結果と照合 する。ワンパス試験では、除去率に対する吸込口濃度、温・湿度、機 器処理風量による影響を明らかにし、さらに、実用化に向けて再現 性を確認する。

定常発生法・ワンパス試験による実験では、HCHO ガスを定常発 生させる方法として 3.1(4)に述べた HCHO 発生装置ではなく、簡易 的な発生器具を新たに考案して採用し、本試験方法が空気清浄機の HCHO 除去性能試験方法として容易でかつ汎用性のあるものになる よう試みた。この $\mathrm{HCHO}$ 発生器具は、ホルマリン溶液をメスシリン ダーに入れて密封し、小型ポンプから流入する清浄空気をガラスボ ールフィルタでメスシリンダー内に搪散させ、溶液表面に吹き付け ることによって HCHO ガスにし、これをテフロンチューブで給気ダ クトに接続して供給するものである。メスシリンダーはチャンバー 外部の恒温実験室内に設置し、ポンプからの流量を調節することに

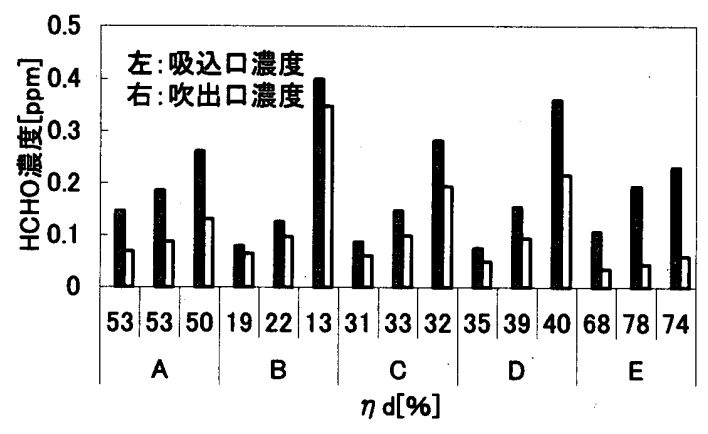

図 8 濃度減衰法:ワンパス試験による実験結果

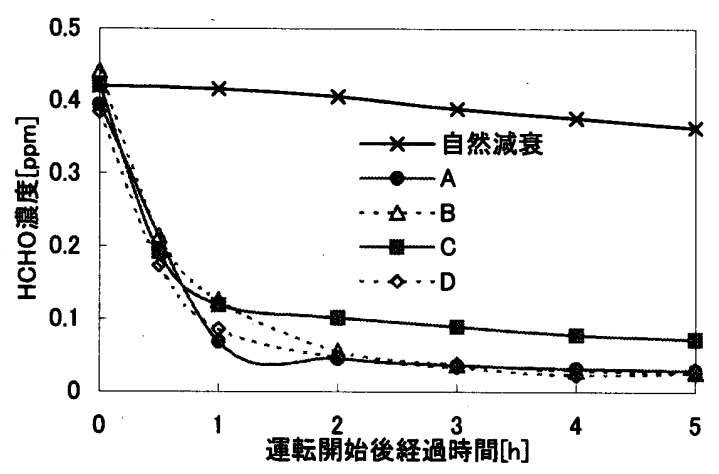

図 9 濃度隇衰法·再循環試験による実験結果

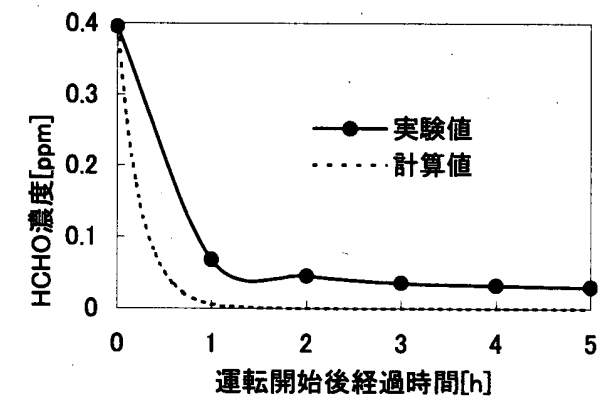

図 10 濃度隇衰法·再循環試験における チャンパー内濃度の時間変化(実験値)と計算值く機種 $\mathrm{A}>$

より、HCHO 発生量を変化させることができる。

\section{2 実験条件}

まず、ワンパス試験では、上述した 3 つ検討項目にあわせて、 以下のように実験条件を設定した。

(a) 温・湿度と吸込口濃度をパラメータとする実験

1) 実験対象：除去原理が異なる機種 Aおよび $\mathrm{B}$

2) 機器処理風量 : カタログ值 $120 \mathrm{~m}^{3} / \mathrm{h}$ に最も近い運転モードの 風量(表 2 網掛けの風量)

3) 温·湿度 : 表 3 に示す 6 パターン

4) 吸込口濃度 : 0.2、0.1、0.05ppm の 3 段階

(b) 機器処理風量をパラメータとする実験

1) 実験对象 : 5 機種すべて

2) 機器処理風量 : 機種 B およびDの「微風」運転モードを除き、 表 2 に示した実測による 3 段階の処理風量

3) 温·湿度 : $25^{\circ} \mathrm{C} 、 60 \% \mathrm{RH}$ 
4) 吸込口濃度 : $0.2 \mathrm{ppm}$ 前後

(c) 試験方法に関する再現性の確認 : 実験(a)(b)において、それぞれ の条件下で 3 回連続して測定し、標準偏差值を求める。

また、再循環試験では、以下の条件下で実験を行った。

1) 実験対象 : 5 機種すべて

2) 機器処理風量 : 機種 B およびDの「微風了運転モードを除き、 表 2 に示した実測による 3 段階の処理風量

3) 温·湿度 : $25^{\circ} \mathrm{C} 、 60 \% \mathrm{RH}$

4) $\mathrm{HCHO}$ 発生量 : $1.6 \sim 2.1 \mathrm{mg} / \mathrm{h}$ (チャンバー内平衡濃度 $0.2 \mathrm{ppm}$ に相当)

各実験において、HCHO 濃度の測定は DNPH-HPLC 法とし、5〜 10 分間で $10 \mathrm{~L}$ を捕集するようにした。

\section{3 結果および考察}

はじめに、ワンパス試験における各実験の結果と考察を述べる。

(a) 温·湿度および吸込口濃度と除去率との関係

ここには図示していないが、機種 $\mathrm{A}$ および B とも、 $\eta$ op は吸込口 濃度にほとんど左右されないことがわかった。

図 11 および 12 に、温・湿度を変化させた場合における、機種 $\mathrm{A}$ および B の ク OPを示す。いずれの機種も、吸込口濃度にかかわらず ほぼ同じ除去率が得られることがわかったので、各温·湿度条件にお ける 3 段階の吸込口濃度の場合の 3 回の測定、つまり 9 データを平 均して図示している。

機種 A は温度、機種 B は湿度によって除去率が影響される傾向が 認められた。機種 A は添着活性炭フィルター、機種 B は光触媒によ る HCHO 除去機構を持っており、活性炭は温度上昇にともなって吸 着速度が減衰する、光触媒は反応にある程度の水分が必要である、 という除去原理から推測できる傾向と符合している。したがって、 除去原理によっては、温度や湿度を段階的に変化させた性能試験を 行う必要がある。

(b) 機器処理風量と除去率との関係

図 13 に、機器処理風量を変化させた場合における、5機種の $\eta O P$ を示す。ここに $ク$ OPは、各処理風量において 3 回連続して測定を行 った結果の平均値である。

ほとんどの空気清浄機は、処理風量の増加にともなってクOP が低 下する傾向にあり、污染空気の除去機構との接触時間が短いほど除 去率が低下することが確認できた。ただし、機種 Eについては、化 学物質過敏症の患者用に製作された特殊な空気清浄機であり、改質 活性炭が大量に内藏されているため、本機の運転モードにおける処 理風量程度では、 $\eta_{O P}$ は $60 \sim 66 \%$ と同程度であった。

(c) 試験方法の再現性について

実験(a)では、各条件下における 3 回の測定値がほぼ同值であり、 再現性が認められた。

実験(b)では、各処理風量ごとにク $O P$ を連続して 3 回測定したが、 機種 B および D は、他の機種に比べて処理風量ごとのばらつき、つ まり 3 回の測定結果から算出した標準偏差值が大きく異なっていた。 たとえば、機種 B の標準モード運転時 $\left(112.7 \mathrm{~m}^{3} / \mathrm{h}\right)$ における標準偏差 は 1.8 であったが、他の処理風量では 0.3〜0.5であった。機種 B お よびD は、除去原理が化学分解式であり、空気清浄機を通過する空 気中の HCHO と分解機構との接触がフィルターの上うに面的では ないので、安定した HCHO 除去率が得られなかったものと考えられ
表 3 定常発生法・ワンパス試験における央験条件マトリクス

\begin{tabular}{|c|c|c|c|}
\hline 温度 $\left[{ }^{\circ} \mathrm{C}\right]$ & 15 & 25 & 35 \\
\hline 40 & 0 & 0 & \\
\hline 60 & 0 & 0 & 0 \\
\hline 80 & & 0 & \\
\hline
\end{tabular}

※のの条件で実験を行った。

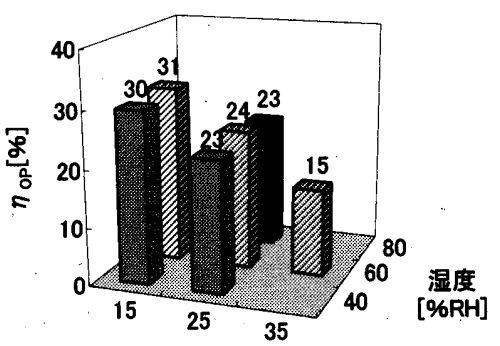

温度 $\left[{ }^{\circ} \mathrm{C}\right]$

図 11 温·湿度とワンパス除去率の関係く機種 $\mathrm{A}>$

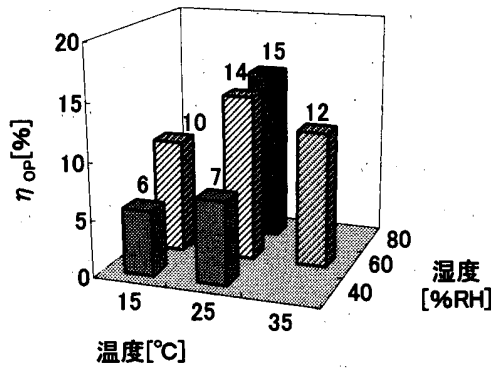

図 12 温·湿度とワンパス除去率の関係〈機種 B $>$

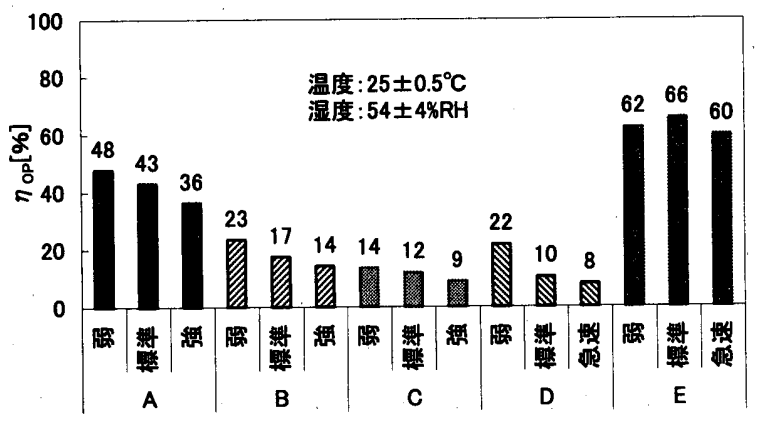

图 13 機器処理風量とワンパス除去椊の関係

る。一方、機種 C は 3 回の測定値が若干低下する傾向にあった。機 種 C は、污染空気が吸込口から入ってまず除去フィルターを通過す るタイプであり、このフィルターから $\mathrm{HCHO}$ が再放散されたか、フ イルターを通過しようとする HCHO を他の化学物質がさえぎった ために、HCHO 発生開始から 3 回の実験が終了するまでのわずか 1 時間程度の間で、除去率がわずかながら低下してしまったと推察さ れる。

次に、再循環試験の結果について考察する。

図 14 および 15 に、例として機種 $\mathrm{A}$ およびCの再循環試験におけ るチャンバー内 $\mathrm{HCHO}$ 濃度の時間变化(実験値)と、先のワンパス試 験で得られた除去率から算出した予測值(計算值)とを示す。チャン 
バー内濃度の减衰曲線は、運転前の定常濃度から発生量を算出し、 実測によるチャンバー内換気量と機器処理風量、チャンバーの気積

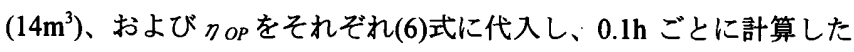
値を示している。

再循環試験による実験結果は、機種 C を除き、空気清浄機運転開 始後 30 分で HCHO 濃度が大きく减少し、2〜3 時間後にはほほ濃度 が安定していた。また、(6)式によって得られた予測值は、実験值よ りも平衡濃度が若干小さいが、機種 $\mathrm{C}$ 以外は実験值と計算值に大き な差がなく、定常発生法・ワンパス試験によって得られた除去率は、 実用上十分な精度を有することが示唆された。機種 Cについては、 内蔵されているフィルターが他の機種に比べて小型で、処理空気と の接触面積が小さく、先のワンパス試験においても時間の経過にと もなって除去率がわずかに低下する傾向が認められており、除去率 も時間 $\boldsymbol{t}$ の関数になっているために計算值と実験值が一致しない結 果になった。実際の居室における空気清浄機の利用を考虑すると、 運転開始後数時間で除去率が低下するような機種は実用的とはいい がたく、機種 Cのみについてあらためて予測式を求める必要性はな いと判断した。

\section{7. 性能試験方法に関する考察}

\section{1 濃度隇衰法および定常発生法の比較・検討}

表 4 に、5 機種の空気清浄機について、濃度堿衰法および定常発 生法のワンパス試験の結果に基づいて、初期漂度 $0.2 \mathrm{ppm}$ 、表 2 の網 掛けで示した処理風量の条件下で算出した除去率 $\eta_{d}$ およびク $O P$ を 示す。

すべての機種について、定常発生法よりも濃度減衰法によって得 られた除去率のほうが高く、同值とならなかった。5.3で述べたよ うに、濃度減衰法では、機種ごとに異なる除去率は得られたものの、 その除去率を用いて予測したチャンバー内 HCHO 濃度の時間変化 と、再循環試験における実験值は一致しなかった。濃度減衰法は、 空気清浄機の運転によるチャンバー内濃度の経時変化が著しく、 DNPH-HPLC 法による潾度測定から正確な除去率を得ることができ ない想念がある。一方、定常発生法では、短時間に除去率が低下す るような機種でない限り、ワンパス試験によって得られた除去率か ら予測したチャンバー内濃度の時間変化と、再循環試験の結果はほ ぼ一致した。ここで検討した定常発生法は、安価で簡易な HCHO 発 生装置を用いており、一定の温·湿度で清浄空気を供給できる空調機 と、温調可能な実験室があれば塞施できる。以上のことから、定常 発生法によるワンパス試験は、空気清浄機の性能試験方法として実 用的かつ汎用性があると考えられる。

\section{2 定常発生法による他ガス成分に対する除去性能試験}

定常発生法・ワンパス試験は、フィルター性能試験方法と同様に、 空気清浄機の除去率を容易に得ることができることがわかった。そ こで、他の単体ガス成分として、一般に住宅において多量に放散さ れ、かつ、厚生労働省の規制対象となっているトルエンおよびキシ レンについて、同様の試験を行った。

図 16 に、トルエンおよびキシレンに対する、5機種のワンパス除 去率 $\eta_{O P}$ を示す。除去率を算出するための濃度測定は、空気清浄機 の吸込口および吹出口の空気の一部をテドラーバッグに採取し、 PID 簡易型 GC-MS で定量分析(分析時間：15min)している。成分に

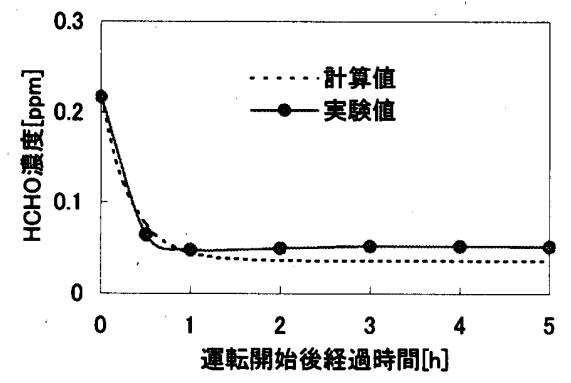

图 14 定常発生法·再循環試験におけるチャンパー内 $\mathrm{HCHO}$ 濃度の時間変化(実験值)および計算值く機種 $\mathrm{A}>$

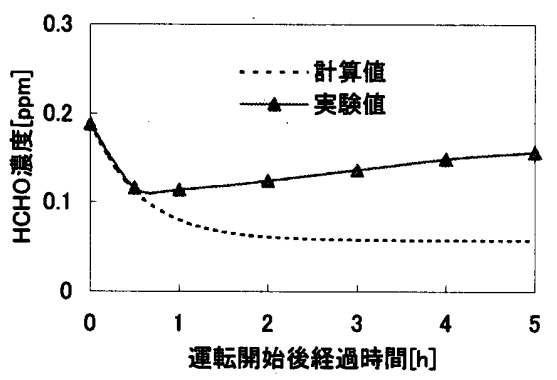

図 15 定常発生法·再循環試験におけるチャンパー内 $\mathrm{HCHO}$ 濃度の時間変化(実験値)および予測值く機種 $\mathrm{C}>$

表 4 除去率 $\eta_{d}$ と $\eta_{O P}$ の比較

\begin{tabular}{|c|c|c|c|c|c|}
\hline 機種 & $\mathrm{A}$ & $\mathrm{B}$ & $\mathrm{C}$ & $\mathrm{D}$ & $\mathrm{E}$ \\
\hline$n_{d}$ & 53 & 22 & 33 & 39 & 78 \\
\hline$\eta_{O P}$ & 36 & 17 & 14 & 22 & 62 \\
\hline
\end{tabular}

※單位は\%。機器好理風量は表 2 網掛けの值。

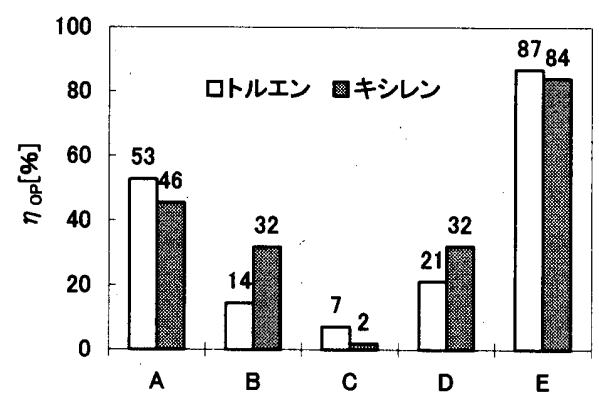

図16 他ガス成分に対するワンパス除去率

よって除去率は異なるが、機種間の相対的な順位はほぼ同じであっ た。

図 17 および 18 に、トルエンおよびキシレンを対象ガスとした、 機種 $\mathrm{E}$ の再循環試験におけるチャンバー内濃度の時間変化(実験值) と、先のワンパス試験で得られた除去率から(6)式により算出した予 測値(計算値)とを示す。HCHO の場合と同様に計算值と実験值は非 常によく一致しており、単体ガス成分に対する空気清浄機の除去性 能試験方法としては、定常発生法による $2 つ の$ 試験方法のいずれも 有用であるといえよう。特にワンパス試験は、簡易な装備と操作性 といった点で、将来的に複数のガス成分を混合して試験を行うなど の応用ができ、実用上最適な試験方法であると考える。 
図 19 に、3つのガス成分に対する $\eta O P$ にその試験における空気 清浄機の処理風量 $Q_{R}$ を乗じた相当換気量 $Q_{e q}$ を示す。機種 C 以外の 4 機種は、トルエンやキシレンといった VOCs 成分の単体ガスに対 しても、HCHO と同等かそれ以上の除去効果を有することがわかる。 また、それぞれのガス成分ごとに除去率は異なるものの、機種間で 相対的に除去効果を比較することは可能であるといえよう。この「相 当換気量」という指標は、空気清浄機を運転した場合に得られる清浄 空気の量を示しており、新鮮空気を取り入れた場合の換気量と同等 の、実空間に適用した場合における除去性能をあらわしていると考 えられる。

以上の結果から、除去原理にかかわらず、単体ガス成分に対する 空気清浄機の除去性能を明らかにするためには、チャンバー気積や 機器処理風量に依存せず正確な除去率が得られる定常発生法・ワン パス試験がもっとも実用的かつ有用であり、現行の規格を本方法の ように修正することを提案する。

\section{8. まとめ}

単体ガス成分に対する家庭用空気清浄機の除去性能について、ス テンレス製大型チャンバーを用い、HCHO ガスを対象に「濃度减衰 法」によるワンパス試験およびJEM 規格に相当する再循環試験、「定 常発生法」によるワンパス試験および再循環試験を実施した。これら の実験結果から以下のことがらがわかった。

(1) 除去原理にかかわらず、機器単体の除去性能が明らかになり、 実空間における除去性能と近似した除去率が得られるのは、定常発 生法・ワンパス試験である。

(2) 定常発生法・ワンパス試験において得られる除去率 $\eta$ op は、空 気清浄機の基本的な除去性能を正確にあらわすことができる指標で あり、これに機器処理風量を乗じて得られる相当換気量は、実空間 における低减勃果をあらわす。

(3) ワンパス除去率は、採用している除去原理が活性炭のような物 理吸着型の場合は温度、光触媒の場合は湿度の影響を受けやすい。 したがって、除去原理によっては、温度や湿度を変化させた性能試 験を行い、ワンパス除去率との関係を把握するべきである。

今後は、多種のガス成分を混合した場合について同様の性能試験 を行い、より実空間に近い条件下における家庭用空気清浄機の除去 性能を明らかにすることが望まれる。

\section{謝辞}

本研究は、科学技術庁科学技術振興調整費(生活-社会基盤研究生活 者ニーズ対応研究「室内科学物質空気污染の解明と健康·衛生居住環 境の開発」)に基づいて設けられた建勧学会学術委員会·室内化学物 質空気污染調査研究委員会(委員長:村上周三 東京大学生産技術研 究所(当時))の活動の一環として実施したものである。関俰者各位に 深甚なる謝意を表す次第である。

\section{本論文に関連する大会発表梗概等}

1) 羽田崇秀、長谷川麻子、小䄈己 : 家庭用空気清浄機によるホルムアルデ ヒド(HCHO)除去性能の評価に関する研究(その 1)化学物質除去基本性能評価 用試驗装置の性能について、日本建築学会大会学術講演梗概集 (東北)、 pp.865-866、2000

2) 羽田崇秀、長谷川麻子、小峯裕己、鎌田元康 : 家庭用空気清浄機による木

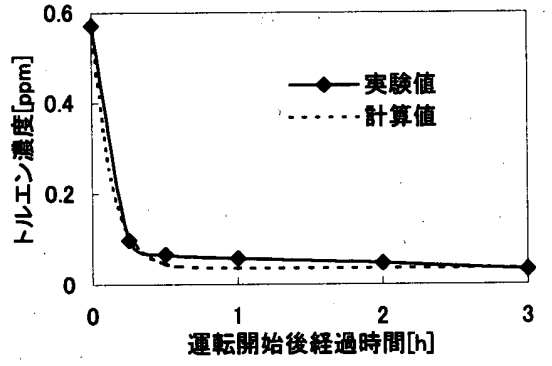

図 17 定常発生法·再循環試験におけるチャンバー内 トルエン濃度の時間変化(実験值)および予測値く機種 E>

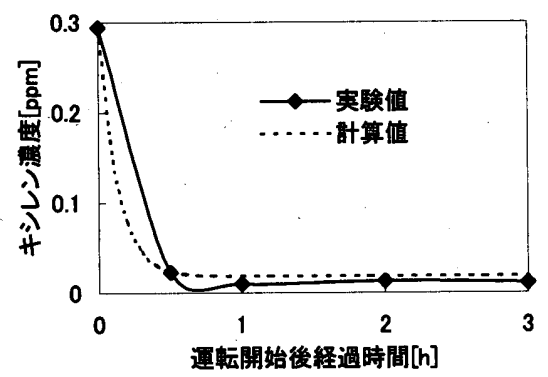

図 18 定常発生法·再循環試験におけるチャンバー内 キシレン濃度の時間变化(実験值)およひ予測值く機種 $\mathrm{E}>$

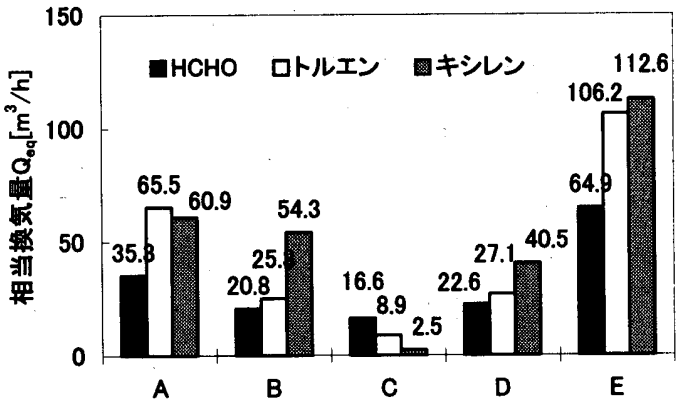

図 19 各ガス成分に対する相当換気量 $Q_{e q}$

ルムアルデヒド(HCHO)除去性能の評価に関する研究(その 2)性能評価指標お よび試験方法の検討、日本建築学会大会学術講演梗概集(関東)、pp.883-884、 2001

3) 羽田崇秀、長谷川麻子、小筆裕己、鐮田元康 : 家庭用空気清浄機による木 ルムアルデヒド(HCHO)除去性能の評価に関する研究(その 3)考案したワンパ ス除去率試験方法の提案と VOCs に対する除去性能、日本建築学会大会学術 講演梗概集(北陸)、pp.989-990、2002

\section{参考文献}

1) (社)日本電機工業会：JEM1467 家庭用空気清浄機、1995

2)(財)日本規格協会：JIS C 9615 空気清浄機、1995

3) (財)日本規格協会 : JS B 9901 ガス除去フィルタ性能試験方法、1997 4) 野㟝淳夫、饭倉一雄、大㵻元毅、吉澤晋 : 家庭用空気清浄機のカスス状物質 除去特性に閔する研究(その 1)ホルムアルデヒドに対する除去効果、日本建築 学会計画系論文集、No.554、pp.35-40、2002

5)(財)日本規格協会：JIS C 9603 換気扇、1988

6) たとえば、厚生労働省 : シックハウス(室内空気污染)問題に関する検討会 中間報告書、2000

(2002年11月 7 日原稿受理, 2003 年 7 月 8 日探用決定 